\title{
Development and Validation of RP-HPLC Method for Estimation of Curcumin from Nanocochleates and Its Application in in-vivo Pharmacokinetic Study
}

\author{
Sameer Nadaf ${ }^{1}$ and Suresh Killedar ${ }^{1}$ \\ ${ }^{1}$ Sant Gajanan Maharaj College of Pharmacy, Mahagaon-416503, Maharashtra, India. \\ *Corresponding author: E-mail: sam.nadaf@rediffmail.com
}

Received: 02-07-2020

\begin{abstract}
A reliable RP-HPLC analytical method with UV detection at $421 \mathrm{~nm}$ was developed and validated for the quantitative determination of curcumin from rat plasma after oral administration of curcumin loaded nanocochleates (CU-NC) to rats. The chromatographic separation was performed on HIQ SIL, C18 (250 mm $\times 4.6 \mathrm{~mm})$ column using methanol and water $(80: 20 \mathrm{v} / \mathrm{v})$ as mobile phase, at $1.0 \mathrm{~mL} / \mathrm{min}$ flow rate. Validation parameters included linearity, accuracy, precision, and limit of quantitation and detection. Good linearity was obtained over the range of $2.5-100 \mu \mathrm{g} / \mathrm{mL}\left(\mathrm{R}^{2}\right.$ $=0.9979$ ) of curcumin. The developed HPLC method was precise, with $<2 \%$ relative standard deviation. Accuracy, stability, and robustness studies were also found to be acceptable. Bland-Altman plot showed an acceptable repeatability coefficient. The method was under statistical control, revealed by a control chart. After CU-NC administration, pharmacokinetic parameters i.e. $\mathrm{C}_{\max }, \mathrm{AUC}_{0-\infty}$, and $\mathrm{AUMC}_{0-\infty}$, were observed to be $97.69 \pm 10.84 \mu \mathrm{g} / \mathrm{mL}, 1402.77 \pm$ $9.67(\mu \mathrm{g} / \mathrm{mL}) \cdot \mathrm{h}$, and $35140.16 \pm 14.67(\mu \mathrm{g} / \mathrm{mL}) \cdot \mathrm{h}^{2}$, respectively. This simple and precise method can be effectively implemented for routine analysis.
\end{abstract}

Keywords: Capability analysis; HPLC-UV method; control chart; curcumin; nanocochleates; rat plasma; bioavailability; biodistribution.

\section{Introduction}

Curcumin, a phytochemical isolated from Curcuma longa rhizomes, is widely recognized for its several health benefits including antitumor activity against different tumor cells. ${ }^{1-5}$ Curcumin is regarded as safe and can be administered at high dosage. Despite its effectiveness and curative potential, the use of curcumin as an anticancer agent is restricted due to poor aqueous solubility, poor tissue absorption, rapid systemic clearance, faster metabolism, rapid degradation at neutral-alkaline $\mathrm{pH}$, and impaired tumor targeting. ${ }^{6-8}$ To override these drawbacks, different nanoparticulate drug delivery systems such as liposomes, solid lipid nanoparticles, nanostructured lipid carriers, polymeric nanoparticles, micelles, and nanoemulsions, have been investigated. ${ }^{9}$ On the same ground, we prepared the curcumin loaded nanocochleates (CU-NC) using solvent evaporation technique to avoid the problems associated with curcumin absorption. Such a formulation has not been reported earlier. Nanocochleates (NC) are stable rod-shaped phospholipid-cation precipitates and rolled cylindrical structures that can offer attractive characteristics, for example, improved efficacy, biocompatibility, and reduced side effects. ${ }^{7}$

Notably, during the fabrication of diverse nanoparticulate systems, the encapsulation methods determine the percentage of encapsulants. In the case of the solvent evaporation technique, the amount of entrapped material is also subjective to partitioning between aqueous and organic phases. ${ }^{10}$ Exact quantification of curcumin is imperative because of the loss or degradation during the formulation of curcumin nanocochleates. Therefore, extensively characterized, reliable, and validated analytical methods are needed for quantitative estimation of curcumin in biological samples and pharmaceutical formulations, as it could influence the estimation and interpretation of pharmacokinetic data. ${ }^{1,10-12}$

A literature survey revealed several spectrophotometric methods, ${ }^{13-15}$ HPLC methods, ${ }^{1,16-20}$ high-performance thin-layer chromatography (HPTLC) methods, ${ }^{21-22}$ and liquid chromatography-mass spectroscopy (LC-MS) methods ${ }^{23-24}$ for the quantitative determination of cur- 
cumin in biological samples. Nevertheless, HPLC methods with UV detection (HPLC-UV) have been used more frequently compared to other techniques, due to their high sensitivity and precision in the detection of curcumin in biological samples. Few studies on curcumin estimation from pharmaceutical formulations, such as in-situ gelling liquid crystals, ${ }^{1}$ eudragit E 100 nanoparticles, ${ }^{6}$ poly-(lactic-co-glycolic acid), as well as poly-(lactic-co-glycolic acid)-polyethyleneglycol nanoparticles, ${ }^{25}$ ethosomes, and transferosomes ${ }^{8}$ have been reported.

Albeit effectual in determining the curcumin in nanoformulations, hitherto, there is no report on an analytical method for effective quantification of curcumin in the nanocochleates. Further, there are no established HPLC methods involving the validation of the proposed method using statistical techniques like Bland-Altman plot, capability analysis, and control charts.

Bland-Altman plot is a difference plot and more often used in analyzing the agreement between two diverse techniques. It is also helpful to determine the repeatability of a single method on a series of samples. Capability analysis corroborates whether a proposed method is statistically able to meet a set of predetermined specifications or not. Whereas control charts (process-behavior charts) are useful to monitor process changes over time.

In this study, an attempt was made to develop and apply a validated simple and rapid reverse-phase high performance liquid chromatographic (RP-HPLC) method for curcumin estimation in rat plasma after CU-NC administration. Data obtained were processed using novel statistical techniques like Bland-Altman plot, capability analysis, and control chart.

\section{Material and Methods}

\section{1. Chemicals and Reagents}

Sami Labs Limited, Bangalore, India, provided the curcumin as a gift sample. Methanol used was of HPLC grade and purchased from Merck Chemicals, India. Analytical grade ethanol and Tween 80 were procured from Merck Chemicals, India. Phosphatidylcholine (Phospholipon 90G) was a gift by Lipoid GmbH Ludwigshafen, Germany. Cholesterol was purchased from Research-Lab Fine Chem Industries Ltd, Mumbai, India. All other chemicals and reagents used were of analytical grade.

\section{2. HPLC Method Development}

\section{2. 1. Instrumentation}

Analysis of curcumin was performed using RP-HPLC (Model LC-4000 Jasco, Japan) equipped with a pump (Jasco, PU-4180) and a $20 \mu \mathrm{L}$ sample injector. The flow rate and run time were $1.0 \mathrm{~mL} / \mathrm{min}$ and $10 \mathrm{~min}$, respectively. Chromatographic separation was achieved on HIQ SIL, C18 T-5 column $(250 \mathrm{~mm} \times 4.6 \mathrm{~mm}$; $5 \mu \mathrm{m})$ using UV-Vis (Jasco,
UV-4075) detector operated at C1 channel at an analytical wavelength of $421 \mathrm{~nm}$. Instrument operation was controlled using 'Chromonav version 2.2' software.

\section{2. 2. Selection of Mobile Phase}

In the extensive preliminary experiments aimed for chromatographic estimation of curcumin in rat plasma, two combinations, namely acetone: water and methanol: water were tested at different ratios (45:55 v/v to 95:05 v/v) and different $\mathrm{pH}$ values. The composition was selected based on the number of theoretical plates and peak separation achieved. The mobile phase was degassed every time and filtered through a $0.45 \mu \mathrm{m}$ membrane filter before use.

\section{2. 3. Stock and Working Solutions of Curcumin in Plasma}

Stock solution $(100 \mathrm{mg} / \mathrm{mL})$ of curcumin was prepared in triplicate by dissolving $100 \mathrm{mg}$ of curcumin in $100 \mathrm{~mL}$ of methanol and used to spike whole rat plasma. The plasma calibration standards were prepared by spiking $900 \mu \mathrm{L}$ of blank plasma with the appropriate quantity of standard solution to get final concentrations of 2.5, 5, 10, $25,50,75$, and $100 \mu \mathrm{g} / \mathrm{mL}$. Stock solution and working standards were appropriately stored in a tightly-stoppered container at $2-8{ }^{\circ} \mathrm{C}$ until HPLC analysis.

\section{2. 4. Preparation of Calibration Curve}

All the calibration standards were injected into the HPLC system in triplicate and analyzed at $421 \mathrm{~nm}$. Peak area vs. drug concentration was plotted to obtain a calibration curve.

\section{2. 5. Drug Extraction from Plasma}

$200 \mu \mathrm{L}$ of methanol was added to the plasma sample $(0.2 \mathrm{~mL})$ to facilitate the protein precipitation. The mixture was then vortexed for $1 \mathrm{~min}$ and subjected to centrifugation at $4000 \mathrm{rpm}$ for $10 \mathrm{~min}$ to separate the precipitate from the organic phase. A clear supernatant aliquot (20 $\mu \mathrm{L}$ ) was loaded in the system.

\section{3. Analytical Method Validation}

\section{3. 1. Selection of Wavelength}

A working solution of $10 \mu \mathrm{g} / \mathrm{mL}$ concentration was scanned in the visible range $(400-800 \mathrm{~nm})$ to obtain the wavelength corresponding to maximum absorption.

\section{3. 2. System Suitability}

Six replicates of standard solution $(10 \mu \mathrm{g} / \mathrm{mL})$ were analyzed using proposed method considering the tailing factor $(<1.5)$, relative standard deviation (\% RSD) of peak 
area, retention time, and theoretical plate count $(>3000)$ as accepted parameters. ${ }^{6}$

\subsection{Specificity and Selectivity}

Method selectivity was established by analyzing curcumin and methanol extracted blank rat plasma samples $(n=6)$, to monitor endogenous interference of plasma components during estimation of the curcumin. ${ }^{1,26}$

\subsection{Linearity}

To determine linearity, curcumin working standards prepared in the concentration range of $2.5-100 \mu \mathrm{g} / \mathrm{mL}$ were injected in triplicate to the HPLC system. Linearity was evaluated by the least-squares regression, Shapiro-Wilk test, and one-way analysis of variance (ANOVA) $(\alpha=0.05)$.

\section{3.5. Accuracy}

The accuracy of the method was determined by performing recovery experiments. To the previously analyzed standard curcumin solution, a known quantity of solution was spiked at different levels in triplicate and reanalyzed by the proposed method. The recovery was determined using the following equation $1^{15,27}$

$$
\begin{aligned}
& \% \text { Recovery }= \\
& =\frac{(\text { Detected amount }- \text { Standard amount })}{\text { Spiked amount }} \times 100
\end{aligned}
$$

\section{3. 6. Precision}

To determine repeatability (intraday precision) and inter-day (intermediate) precision, working standard solutions $(5,10$, and $25 \mu \mathrm{g} / \mathrm{mL})$ were injected in triplicate to the HPLC system. To determine intraday precision, working standards were analyzed at seven-time intervals on the same day, whereas inter-day precision was determined by analyzing samples on the three consecutive days using the proposed method. The obtained data were expressed as \% RSD and processed statistically by two-tailed student's $t$-test $(p<0.05) .1,15,26$

\subsubsection{Sensitivity}

LOD and LOQ were determined from the calibration curve to estimate the sensitivity of the proposed method using the following equations 2 an 3

$$
\begin{aligned}
\mathrm{LOD} & =\frac{3 \sigma}{\mathrm{b}} \\
\mathrm{LOQ} & =\frac{10 \sigma}{\mathrm{b}}
\end{aligned}
$$

where ' $\sigma$ ' is the standard deviation of the y-intercept of the regression line, and ' $\mathrm{b}$ ' is the slope of the calibration curve. ${ }^{15,20,27}$

\section{3. 8. Robustness}

Optimized parameters were customized and a standard solution of curcumin was injected in triplicate to determine the robustness of the proposed method. The ratio of methanol in the mobile phase, flow rate, and wavelength was varied by $\pm 0.2 \%, \pm 0.1 \mathrm{~mL} / \mathrm{min}$, and $\pm 2 \mathrm{~nm}$, respectively. ${ }^{28,29}$ The $\%$ assay, retention time, and theoretical plate count were determined.

\subsection{Ruggedness}

To determine the ruggedness, the same standard solutions were injected by different analysts under analogous operating conditions. ${ }^{29}$

\section{3. 10. Stability}

Stability assessment of the working solutions provides the effect of each storage period on the curcumin concentration. Obtained outcomes were compared with the initial concentration (zero cycle). ${ }^{26}$

Short-term and long-term stability

Short-term stability and long-term stability of working standards prepared at three different quality control levels $(5,10$, and $25 \mu \mathrm{g} / \mathrm{mL})$ were determined by storing the samples at room temperature for $24 \mathrm{~h}$ and $-20{ }^{\circ} \mathrm{C}$ for 30 days, respectively. After a specified time, samples were analyzed and compared with the freshly prepared samples.

Freeze-thaw stability

Working solutions $(\mathrm{n}=3)$ prepared at three different levels were initially frozen for $24 \mathrm{~h}$ and then thawed at room temperature for $2 \mathrm{~h}$. This cycle was repeated for three times and meanwhile, the solutions were analyzed and compared with the freshly processed samples. ${ }^{26,30}$

\section{4. Statistical Analysis of the Proposed Method}

\subsubsection{Normality of the Data and Outlier Detection}

To examine the normality of data, a normal quantile-quantile plot (Q-Q plot) was constructed. Data were processed by the Shapiro-Wilk test and the Shapiro-Francia test for normal distribution. Data distribution, variability, and outliers were detected using Grubbs-double-sided test. ${ }^{15}$

\section{4. 2. Coefficient of Repeatability by Bland- Altman Plot}

Repeatability coefficient (CR, Eq. 4) or precision of a method was determined using the Bland-Altman plot. ${ }^{31,32}$ 


$$
C R=1.96 \times \frac{\sqrt{\sum\left(\mathrm{D}_{2}-\mathrm{D}_{1}\right)^{2}}}{n}
$$

where $D_{2}$ and $D_{1}$ are two measurements.

\section{4. 3. Control Charts}

Control charts were computed to ensure the capability of the projected method to produce precise results.

\section{4. 4. Zone Test}

The zone test verifies whether the process is influenced by variables or not. Control chart was divided equally into Zone A, B, and C. ${ }^{15}$

\section{4. 5. Capability Analysis of the Proposed Method}

Briefly, the working solution of known concentration $(10 \mu \mathrm{g} / \mathrm{mL})$ was prepared and analyzed using HPLC. Lower specification limit (LSL), nominal value, and upper specification limit (USL) were set at 9.85, 10.00, and 10.15, respectively. ${ }^{33}$

Process capability $\left(\mathrm{C}_{\mathrm{p}}\right)$ was calculated using the following equation 5

$$
C_{p=\frac{u S L-L S L}{6 \sigma_{\text {within }}}}
$$

Process capability index (Cpk) was calculated using the following equation 6

$$
C_{p k}=\text { minimum of }\left(\frac{\text { mean-LSL }}{3 \sigma}, \frac{\text { USL-Mean }}{3 \sigma}\right)
$$

$\mathrm{C}_{\mathrm{p}}$ and $\mathrm{C}_{\mathrm{pk}}$ were determined using SPC for Excel and should always be $<1$.

\section{5. Preparation and Characterization of Nanocochleates Containing Curcumin}

\section{5. 1. Formulation of Curcumin Encapsulated Nanoliposomes (CU-NL)}

As stated in our previous report, ${ }^{7}$ nanoliposomes were prepared using an ethanol injection method and Box-Behnken design (data not shown). A total of 17 batches $(100 \mathrm{~mL})$ of CU-NL were prepared by varying the phospholipid concentration (600-750 mg), cholesterol concentration (150-200 mg), and stirring speed (1000-1800 rpm). Briefly, a specified quantity of cholesterol, phospholipid, and curcumin (100 mg), was mixed with ethanol $(20 \mathrm{~mL})$ and heated to form a clear solution. The solution was injected into a cold aqueous phase (100
$\mathrm{mL}$ ) and stirred for $30 \mathrm{~min}$ at specified rotations with high-speed homogenizer (Remi, India) to achieve the even-sized liposomal dispersion. After complete evaporation of ethanol, the dispersion was volume adjusted $(100 \mathrm{~mL})$ and subjected to membrane filtration $(0.45$ $\mu \mathrm{m}){ }^{7}$

\section{5. 2. Formulation of CU-NC}

To the previously formed optimized liposomal dispersion, $0.1 \mathrm{M}$ calcium chloride (50 $\mu \mathrm{L})$ was dropwise added under the vortex to form the cigar-shaped nanocochleates.

\section{6. Characterization of $\mathrm{CU}-\mathrm{NL}$ and CU-NC}

\section{6. 1. Particle Size}

The particle size of CU-NL and CU-NC was determined using dynamic light scattering (DLS) technique (Nano-S90 ZetaSizer, Malvern Instruments, Worcestershire, UK). Samples were adequately diluted with water and analysis was performed in triplicate at a scattering angle of $90^{\circ}$ at $25^{\circ} \mathrm{C}$.

\section{6. 2. Entrapment Efficiency (\% EE)}

$1 \mathrm{~mL}$ of CU-NL and CU-NC were separately transferred to a centrifuge tube and centrifuged at $4000 \mathrm{rpm}$ for $30 \mathrm{~min}$ at $4{ }^{\circ} \mathrm{C}$ in a cooling centrifuge (Remi, India). The supernatant was separated and settled vesicles were disrupted using ethanol to release the entrapped curcumin. Suitable diluted samples were analyzed at $421 \mathrm{~nm}$ and $\% \mathrm{EE}$ was calculated using the following equation 7

$$
\% \mathrm{EE}=\frac{\mathrm{W}_{\mathrm{E}}}{\mathrm{W}_{\mathrm{T}}} \times 100
$$

where $\mathrm{W}_{\mathrm{T}}$ is the total amount of drug added and $\mathrm{W}_{\mathrm{E}}$ is the amount of entrapped drug.

\section{6. 3. Zeta Potential}

Zeta potential of CU-NL and CU-NC were determined using Zetasizer 3000 HSA (Malvern Instruments, Malvern, UK). ${ }^{7}$

\section{7. Application to Pharmacokinetics and Biodistribution Study}

\subsection{Animals}

Different pharmacokinetic parameters were estimated using healthy Wistar albino rats (200-250 g). Animals were kept in the cages and had free access to food and wa- 
ter. The day before the experimentation, rats fasted overnight with the provision of water only.

\section{7. 2. Procedure}

The protocol of the experiment was permitted by the Animal Ethical Committee of Bharati Vidyapeeth College of Pharmacy, Kolhapur, India (Approval No. BVCPK/CPCSEA/IAEC/ 01/15/2017-2020). Briefly, eight animals were assigned randomly into three groups (I, II, and III). Group-I consisting of two animals has received a single oral dose $(50 \mathrm{mg} / \mathrm{kg}$ ) of curcumin suspension (curcumin dispersed in $1 \%$ carboxymethylcellulose), while CU-NL and CU-NC at a dose of $50 \mathrm{mg} / \mathrm{kg}$ (corresponding to curcumin) were administered to group II and III (three animals in each group), respectively. Rats were anesthetized using chloroform and blood $(0.5 \mathrm{~mL})$ was withdrawn at $1,3,6,12$, and $24 \mathrm{~h}$ using retro-orbital puncture technique. Obtained blood samples were centrifuged at $4000 \mathrm{rpm}$ for $10 \mathrm{~min}$ at $4{ }^{\circ} \mathrm{C}$ (Remi, Mumbai, India) to separate the plasma from the whole blood. Plasma samples were stored at $-20{ }^{\circ} \mathrm{C}$ until HPLC analysis using a validated method.

\section{7. 3. Pharmacokinetic Parameters Estimation}

The non-compartmental approach was implemented to determine the pharmacokinetic parameters. Peak plasma concentration $\left(\mathrm{C}_{\max }\right)$ and time to acquire peak concentration $\left(\mathrm{T}_{\max }\right)$ were estimated directly from the individual plasma concentration-time profile. The first-order elimination rate constant $\left(\mathrm{K}_{\mathrm{e}}\right)$ was determined by the linear regression of the terminal data points. The terminal elimination half-life $\left(t_{1 / 2}\right)$, the area under the plasma concentration-time curve $\left(\mathrm{AUC}_{0-\infty}\right)$, area under the first moment time curve $\left(\mathrm{AUMC}_{0_{-}}\right)$, mean residence time $\left(\mathrm{MRT}_{0-\infty}\right)$, clearance $(\mathrm{Cl})$, and apparent volume of distribution $\left(\mathrm{V}_{\mathrm{D}}\right)$ was also calculated. The relative bioavailability $\left(\mathrm{F}_{\text {rel }}\right)$ was calculated as $\mathrm{F}_{\text {rel }}=\left(\mathrm{AUC}_{\mathrm{CU}-\mathrm{NC}} / \mathrm{AUC}_{\text {curcumin }}\right) \times$ 100. Statistical significance between various pharmacokinetic parameters established for the different groups was considered significant at $p<0.05$.

\section{7. 4. Biodistribution Study}

Following the bioavailability study, one rat from each group was sacrificed by cervical dislocation. Different organs like spleen, heart, liver, lung, kidney, and brain were excised, rinsed in ice-cold saline, and blotted to remove excess fluid. Tissues were weighed and subsequently homogenized with a double weight of normal saline. The mixture of homogenate $(200 \mu \mathrm{L})$ was transferred to $200 \mu \mathrm{L}$ of methanol, vortexed for $4 \mathrm{~min}$, and followed by centrifugation at $4000 \mathrm{rpm}$ for $10 \mathrm{~min} .20 \mu \mathrm{L}$ supernatant was separated and analyzed using the proposed HPLC methadCalibration curve of curcumin in rat plasma

\section{Results and Discussion}

3. 1. Optimization of Chromatographic Conditions

The different chromatographic conditions, such as mobile phase composition, flow rate, and the wavelength of analysis, were optimized after several trials. To get the sharp and separated peaks from plasma components, different solvents, viz. acetonitrile, methanol, and water were screened in varying compositions. Acetonitrile-water composition showed better sensitivity but variation in the composition resulted in altered retention time and a lower number of theoretical plate count. Conversely, methanol-water composition showed well-separated peaks of the drug from plasma and exhibited good resolution with reduced tailing, as well as improved theoretical plate count. Hence the mobile phase composition was changed from acetonitrile:water to methanol:water.

Flow rates ranging from 0.9 to $1.1 \mathrm{~mL} / \mathrm{min}$ were tried to evaluate the resolution of plasma and curcumin peak. Low flow rate showed the merging of the peaks whereas broadening was achieved at a higher flow rate. Henceforth, $1 \mathrm{~mL} / \mathrm{min}$ was selected as the optimum flow rate based on higher resolution and theoretical plates. Finally, the $\mathrm{pH}$ of mobile phase consisting of methanol and water $(80: 20 \mathrm{v} / \mathrm{v})$ was adjusted to 4.5 with acetic acid. Curcumin showed maximum absorbance at $421 \mathrm{~nm}$ hence it was selected as detection wavelength. Notably, gradient elution mode showed an inferior separation than the isocratic mode.

\section{2. Extraction Method Optimization}

Different solvents (methanol, diethyl ether, and acetonitrile) were assessed to acquire better extraction efficiency of curcumin from aliquots of rat plasma. As an optimized solvent, screening trials of methanol performed in the range of 100 to $500 \mu \mathrm{L}$ revealed that the best recovery of curcumin was observed at $200 \mu \mathrm{L}$. Methanol showed good extraction efficiency $(98.23 \pm 2.06 \%)$ compared to acetonitrile $(68.27 \pm 3.97 \%)$ and diethyl ether (54.36 \pm $2.81 \%)$, so it was used for subsequent analysis.

\section{3. Method Validation}

\section{3. 1. System-suitability and Specificity}

System suitability testing parameters are the acceptance criteria that must be fulfilled before sample analysis as they corroborate the validity of the developed method. ${ }^{34}$ Six replicates of standard curcumin solution $(10 \mu \mathrm{g} /$ $\mathrm{mL}$ ) were analyzed and evaluated for different principle peak parameters viz. peak area, tailing factor $(\mathrm{T})$, theoretical plate number $(N)$, and retention time $\left(t_{R}\right)$. Detailed results are shown in Table 1. The chromatogram (Fig. 1) shows good peak resolution, indicating the high specificity and selectivity of this method. Being insoluble, no in- 
Table 1. System suitability of the developed method

\begin{tabular}{ccccc}
\hline Sample No. & Peak area & Plate counts & Retention time $(\mathbf{m i n})$ & Tailing factor \\
\hline 1 & 349796 & 3058 & 5.33 & 1.49 \\
2 & 350473 & 3140 & 5.36 & 1.43 \\
3 & 368647 & 3230 & 5.47 & 1.49 \\
4 & 353307 & 3097 & 5.46 & 1.46 \\
5 & 359219 & 3180 & 5.22 & 1.42 \\
6 & 358462 & 3167 & 5.32 & 1.46 \\
Mean & 356650.7 & 3145.33 & 5.36 & 1.46 \\
S.D. & 7072.76 & 61.37 & 0.09 & 0.03 \\
R.S.D. (\%) & 1.98 & 1.95 & 1.75 & 2.01 \\
\hline
\end{tabular}

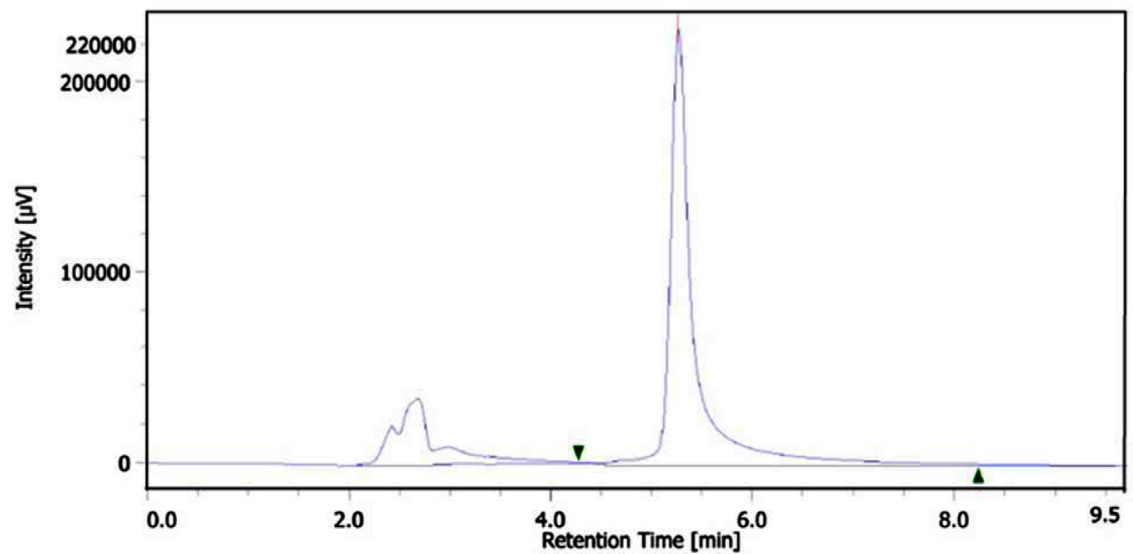

Fig. 1. HPLC chromatogram of curcumin in rat plasma

terference was detected due to excipients and additives. The proposed method meets the acceptance limits of the system suitability.

\section{3. 2. Linearity}

The standard plot of working solutions of curcumin followed the Beer-Lambert law over the concentration range of $2.5-100 \mu \mathrm{g} / \mathrm{mL}$ (Fig. 2). Linear regression equation was found to be $y=30206 \cdot x+54551\left(R^{2}=0.9979\right)$.

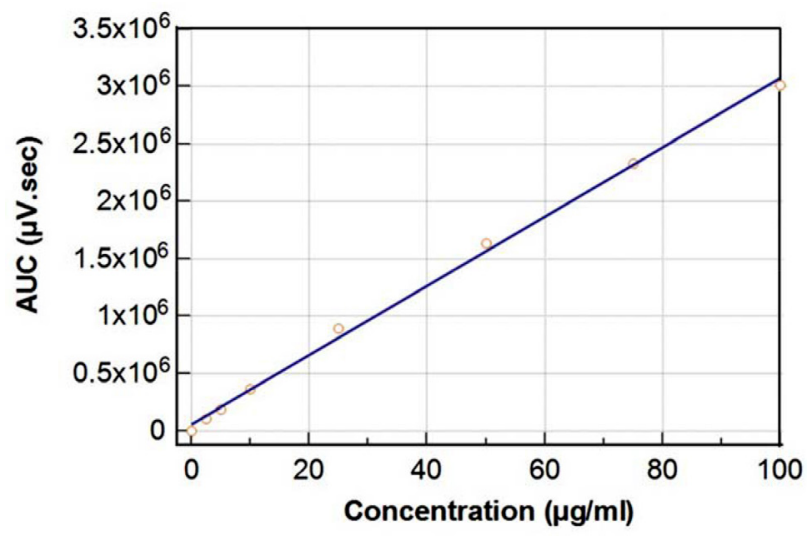

Assay validity was confirmed using ANOVA $(p<0.05)$. Shapiro-Wilk test $(\mathrm{W}=0.92)$ and the D'Agostino-Pearson test $(\mathrm{P}=0.45)$ accepted the linearity of the data. The results of the regression analysis are shown in Table 2.

\subsubsection{Accuracy}

An accuracy study indicated the reliability of the method in the routine analytical application. The \% recovery was ranged from 98.60 to $99.64 \%$ with \%RSD ranging from 1.53 to 1.81 ensuring that the fluctuation in drug concentration can be detected with high accuracy (Table 3).

\section{3. 4. Precision}

As shown in Table 3, intra-day and inter-day precision were ranged from 98.60 to $99.64 \%$ and 96.40 to $99.16 \%$, respectively. Lower \%RSD ensured high precision. Twotailed student's $t$-test showed no significant difference.

\section{3. 5. Sensitivity}

LOD and LOQ are the lowest concentration that can be detected and quantified respectively using the proposed method. LOD and LOQ were found to be $0.09 \mu \mathrm{g} / \mathrm{mL}$ and $0.34 \mu \mathrm{g} / \mathrm{mL}$, respectively. 
Table 2. Regression analysis of the data

\begin{tabular}{|c|c|c|c|c|c|}
\hline \multicolumn{3}{|c|}{$\begin{array}{c}\text { Dependent variable }-\mathrm{Y} \\
\text { Independent variable }-\mathrm{X}\end{array}$} & \multicolumn{3}{|c|}{$\begin{array}{c}\text { AUC }(\mu \mathrm{V} . \mathrm{sec}) \\
\text { Concentration }(\mu \mathrm{g} / \mathrm{mL})\end{array}$} \\
\hline \multicolumn{6}{|c|}{ Least squares regression } \\
\hline \multicolumn{3}{|c|}{ Sample size } & \multicolumn{3}{|c|}{8} \\
\hline \multicolumn{3}{|c|}{ Coefficient of determination $\left(\mathrm{R}^{2}\right)$} & \multicolumn{3}{|c|}{0.9979} \\
\hline \multicolumn{3}{|c|}{ Residual standard deviation } & \multicolumn{3}{|c|}{$5.61 \times 10^{4}$} \\
\hline \multicolumn{6}{|c|}{$\begin{array}{c}\text { Regression Equation } \\
y=5.46 \times 10^{4}+3.02 \times 10^{4} \cdot x\end{array}$} \\
\hline Parameter & Coefficient & Std. Error & 95\% CI & $\mathbf{t}$ & $\mathbf{P}$ \\
\hline Intercept & $5.46 \times 10^{4}$ & $2.73 \times 10^{4}$ & $-1.23 \times 10^{4}$ to $1.21 \times 10^{5}$ & 2.00 & 0.09 \\
\hline Slope & $3.02 \times 10^{4}$ & 563 & $2.88 \times 10^{4}$ to $3.16 \times 10^{4}$ & 53.69 & $<0.0001$ \\
\hline \multicolumn{6}{|c|}{ Analysis of variance } \\
\hline Source & & DF & Sum of Squares & & juare \\
\hline Regression & & 1 & $9.07 \times 10^{12}$ & & $10^{12}$ \\
\hline Residual & & 6 & $1.89 \times 10^{10}$ & & $10^{9}$ \\
\hline \multirow{2}{*}{\multicolumn{3}{|c|}{$\begin{array}{c}\text { F-ratio } \\
\text { Significance level }\end{array}$}} & \multirow{2}{*}{\multicolumn{3}{|c|}{$\begin{array}{c}2883 \\
\mathrm{P}<0.0001\end{array}$}} \\
\hline & & & & & \\
\hline \multicolumn{6}{|c|}{ Residuals } \\
\hline \multicolumn{3}{|c|}{ Shapiro-Wilk test for Normal distribution } & \multicolumn{3}{|c|}{$\begin{array}{c}\mathrm{W}=0.92 \\
\text { accept Normality }(\mathrm{P}=0.45)\end{array}$} \\
\hline
\end{tabular}

Table 3. Precision and accuracy for estimation of curcumin in mobile phase using HPLC

\begin{tabular}{|c|c|c|c|c|c|c|}
\hline \multirow{3}{*}{$\begin{array}{r}\text { Theoretical } \\
\text { concentration } \\
(\mu \mathrm{g} / \mathrm{mL})\end{array}$} & \multicolumn{4}{|c|}{ Intra- and inter-day precision } & \multirow{2}{*}{\multicolumn{2}{|c|}{ Recovery $(\%)^{b}$}} \\
\hline & \multicolumn{2}{|c|}{ Experimental concentration } & \multicolumn{2}{|c|}{ Precision $(\%)^{\mathrm{a}}$} & & \\
\hline & Intra-day & Inter-day & Intra-day & Inter-day & Intra-day ${ }^{c}$ & Inter-day \\
\hline 5 & $4.94 \pm 0.09$ & $4.82 \pm 0.12$ & 1.81 & 2.59 & 99.60 & 96.40 \\
\hline 10 & $9.86 \pm 0.15$ & $9.76 \pm 0.30$ & 1.56 & 3.04 & 98.60 & 97.60 \\
\hline 25 & $24.9 \pm 0.38$ & $24.79 \pm 0.50$ & 1.53 & 1.90 & 99.64 & 99.16 \\
\hline
\end{tabular}

${ }^{a}$ Expressed as relative standard deviation, RSD ${ }^{b}$ Expressed as (mean observed concentration/actual concentration) $\times 100{ }^{\mathrm{c}}$ Expressed as accuracy $(\%)$

\section{3. 6. Ruggedness and Robustness}

Robustness was determined after deliberate modifications in the optimized chromatographic conditions. One way ANOVA showed no significant difference between retention times, theoretical plates, and percent recovery. \%RSD less than 2 assured the reliability, robustness, and

Table 4. Robustness and ruggedness evaluation of the developed method for curcumin

\begin{tabular}{ccccccc}
\hline Parameters & $\begin{array}{c}\text { Changes } \\
\text { incorporated }\end{array}$ & \multicolumn{2}{c}{ Retention time } & \multicolumn{2}{c}{ Theoretical plate } & \multicolumn{2}{c}{ \% assay } \\
& Mean \pm SD (min) & RSD (\%) & Mean \pm SD & RSD (\%) & Mean \pm SD (\%) & RSD (\%) \\
\hline $\begin{array}{c}\text { Mobile phase } \\
\text { composition }\end{array}$ & $80: 20$ & $5.36 \pm 0.09$ & 1.75 & $3145 \pm 61$ & 1.95 & $98.60 \pm 1.63$ \\
(Methanol: & $82: 18$ & $5.44 \pm 0.06$ & 1.18 & $3895 \pm 77$ & 1.97 & $93.64 \pm 1.33$ \\
water) & $78: 22$ & $5.32 \pm 0.10$ & 1.82 & $3079 \pm 49$ & 1.60 & $91.38 \pm 2.35$ \\
Flow rate & 1 & $5.36 \pm 0.09$ & 1.75 & $3145 \pm 61$ & 1.95 & $98.60 \pm 1.63$ \\
(mL/min) & 0.9 & $5.56 \pm 0.11$ & 1.92 & $3544 \pm 55$ & 1.54 & $94.67 \pm 1.55$ \\
& 1.1 & $5.29 \pm 0.09$ & 1.75 & $3792 \pm 76$ & 2.00 & $89.34 \pm 1.37$ \\
Detection & 421 & $5.36 \pm 0.09$ & 1.75 & $3145 \pm 61$ & 1.95 & $98.60 \pm 1.63$ \\
wavelength (nm) & 423 & $5.34 \pm 0.09$ & 1.60 & $3687 \pm 56$ & 1.53 & $93.65 \pm 1.39$ \\
& 419 & $5.35 \pm 0.07$ & 1.21 & $4300 \pm 85$ & 1.99 & $92.350 \pm 1.58$ \\
\hline
\end{tabular}


Table 5. Stability of curcumin in rat plasma at different conditions $(n=3)$

\begin{tabular}{cccccc}
\hline $\begin{array}{c}\text { Concentration } \\
(\boldsymbol{\mu g} / \mathbf{m L})\end{array}$ & \multicolumn{2}{c}{ Short-term stability } & \multicolumn{2}{c}{ Long-term stability } & \multicolumn{2}{c}{ Freeze-thaw stability } \\
Mean \pm SD & RSD (\%) & Mean \pm SD & RSD (\%) & Mean \pm SD & RSD (\%) \\
\hline 5 & $4.92 \pm 0.010$ & 1.95 & $4.88 \pm 0.09$ & 1.93 & $4.69 \pm 0.11$ \\
10 & $9.8 \pm 0.17$ & 1.68 & $9.57 \pm 0.27$ & 2.77 & $9.76 \pm 0.18$ \\
25 & $24.71 \pm 0.44$ & 1.78 & $24.51 \pm 0.15$ & 0.60 & $24.76 \pm 0.26$ \\
\hline
\end{tabular}

validity of the method. Analysis of the same sample by the different analysts also showed more than $98 \%$ of the recovery. Detailed results are shown in Table 4.

\section{3. 7. Stability}

Short term, long term, and freeze-thaw stability for curcumin were evaluated at three different concentration levels $(5,10$, and $25 \mu \mathrm{g} / \mathrm{mL})$. At room temperature, curcumin showed stability for $24 \mathrm{~h}$. The working solutions showed stability in plasma for 15 days and RSD of peak area and retention time was 1.84 and 1.92 , respectively (Table 5). Chromatographic analysis of curcumin working solutions after freeze-thaw cycles indicated no significant degradation and signs of instability.

\section{4. Statistical Analysis of Proposed Method}

\section{4. 1. Normality of the Data and Outlier Detection}

The normal Q-Q plot (Fig. 3) constituted a spike of identical values. The coefficient of skewness and coefficient of kurtosis was found to be $1.04(\mathrm{P}=0.07)$ and -1.46 $(\mathrm{P}=0.19)$. Kolmogorov-Smirnov test $(\mathrm{D}=0.14)$ accepted the data normality. Grubbs-double-sided test $(\alpha=0.05)$ and Tukey's test confirmed the nonexistence of outliers.

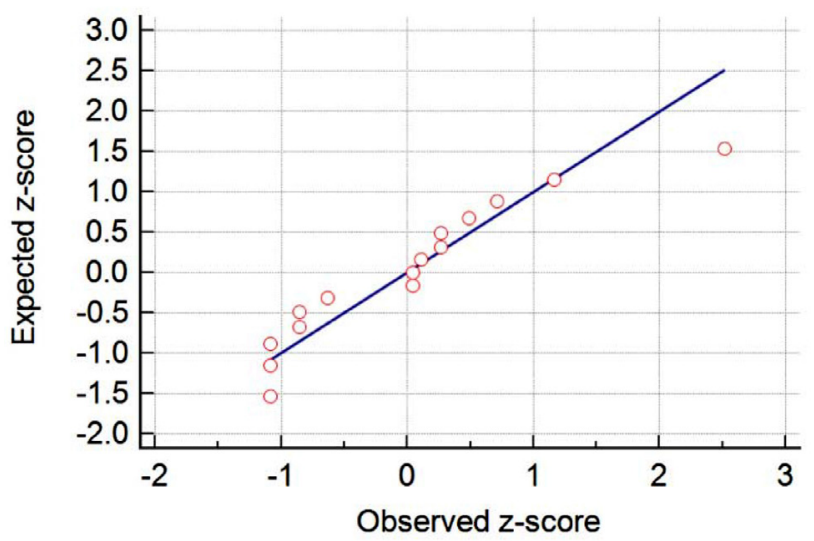

Fig. 3. Quantile-Quantile plot depicting goodness of fit

\section{4. 2. Coefficient of Repeatability by Bland- Altman Plot}

Acceptable repeatability (67.440) was observed. Remarkably, $95 \%$ confidence intervals of the limit of agree-

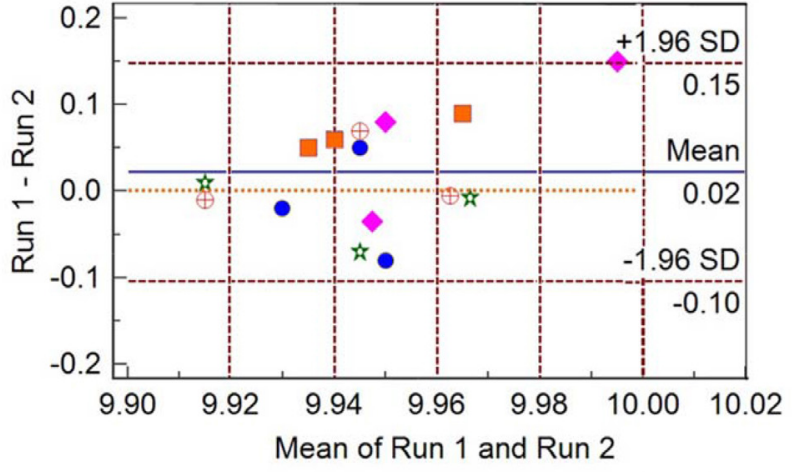

$\oplus$ Day $1 \square$ Day $3 \bullet$ Day 5 \& Day $10 \bullet$ Day 15

Fig. 4. The Bland-Altman plot for repetitive measurements for the same method

ments (LOA) were within the maximum allowed difference between runs, indicative of the closeness of the results (Fig. 4). ${ }^{15}$

\section{4. 3. Control Charts and Zone Test}

Control charts identify the causes of systematic errors and can control the variations in the analytical method. ${ }^{35}$ The absence of analytical points beyond the control limits ensured the nonexistence of special cause variation in the method and no deviation from the predetermined limits. As revealed from Fig. 5, no two measurement value out of three successive results fell in 3 standard deviations (zone A) or beyond, no four out of five succeeding measurement values fell in warning limits (zone B), i.e. 2 standard deviations or beyond, and no seven consecutive re-

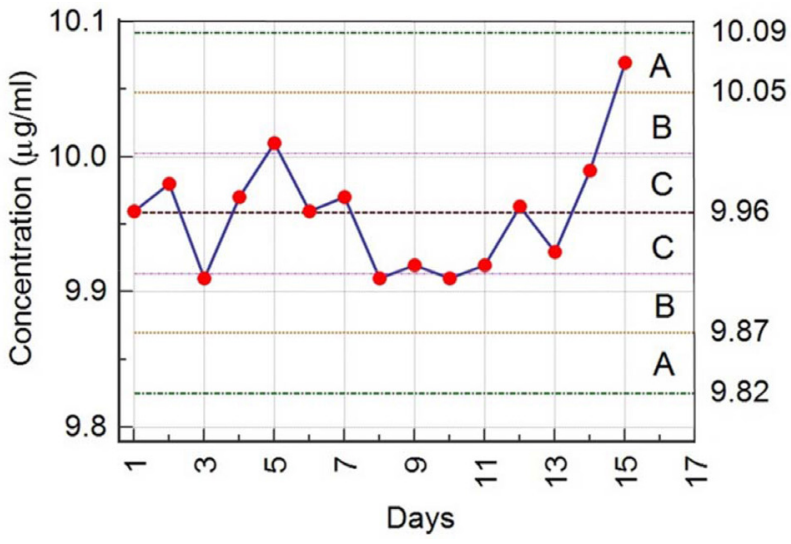

Fig. 5. Control chart showing the accuracy of the method 


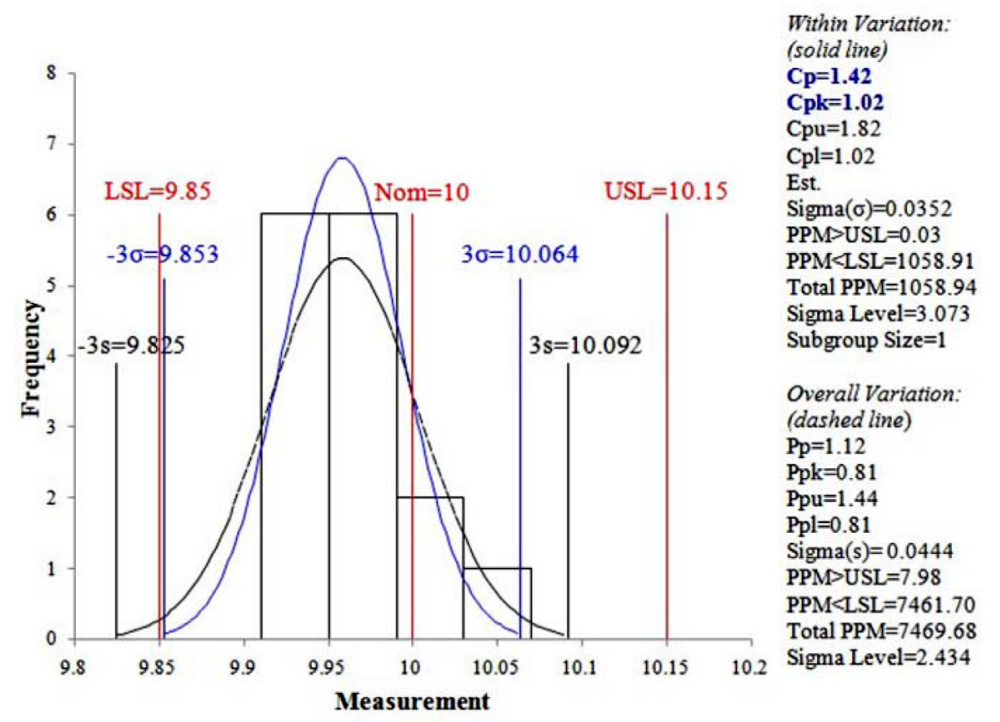

Fig. 6. Capability analysis of the proposed method

sults fell in 1 standard deviation, i.e. zone $\mathrm{C}$ or beyond. No point exceeded the warning limits. Hence, analytical method can be classified as in-control.

\section{4. 4. Capability Analysis of the Proposed Method}

As depicted in Fig. 6, process performance $\left(\mathrm{P}_{\mathrm{p}}\right)$ considers the overall variation, and $\mathrm{C}_{\mathrm{p}}$ uses the within variation. Notably, $6 \sigma$ was less broad than the specification width and the values of $\mathrm{C}_{\mathrm{p}}(1.42)$ and $\mathrm{C}_{\mathrm{pk}}(1.02)$ were $<1$. The developed method can meet the predetermined values consistently with minimum deviation. ${ }^{15}$

\section{5. Characterization of $\mathrm{CU}-\mathrm{NL}$ and CU-NC}

Particle size, zeta potential, and entrapment efficiency of optimized CU-NL and CU-NC are reported in Table 6.

Table 6. Characterization of CU-NL and CU-NC

\begin{tabular}{ccr}
\hline Parameters & CU-NL & CU-NC \\
Particle Size $(\mathrm{nm})$ & $235.64 \pm 11.46$ & $261.27 \pm 8.42$ \\
EE $(\%)$ & $71.55 \pm 4.42$ & $79.67 \pm 5.67$ \\
Zeta Potential $(\mathrm{mV})$ & $-14.51 \pm 2.29$ & $-9.88 \pm 0.70$ \\
\hline
\end{tabular}

\section{6. Application of Method}

\section{6. 1. Pharmacokinetics Study}

The plasma concentration of curcumin in rat plasma samples were estimated for $24 \mathrm{~h}$ after oral administration of CU-NL, CU-NC, and curcumin dispersion (Fig. 7A).

Based on a comparative analysis of all the pharmacokinetic parameters enlisted in Table 7 , it is quite clear that nanocochleates significantly improved the plasma concen-
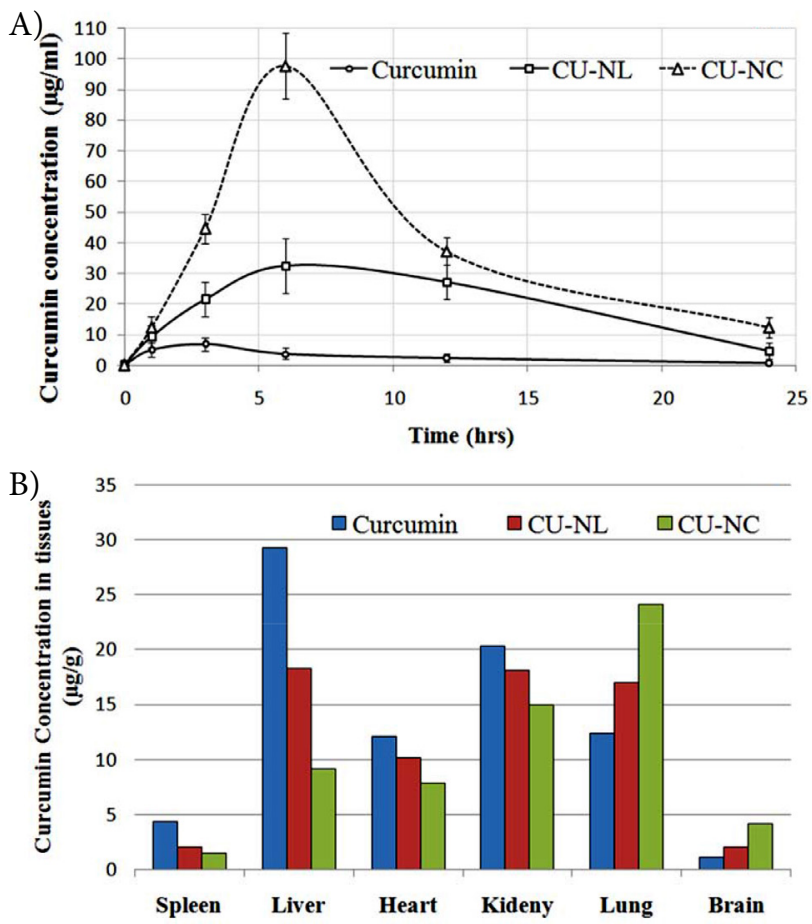

Fig. 7. (A) Mean plasma concentration-time profiles and (B) tissue distribution of curcumin after oral administration of curcumin dispersion, CU-NL and CU-NC in Wistar albino rats

trations of curcumin compared to nanoliposomes and free curcumin. Throughout the study period, the curcumin plasma concentrations in CU-NC administered rats were significantly higher $(P<0.05)$ than CU-NL and curcumin-treated rats. CU-NC demonstrated the 14.1-, 22.1-, 3-, and 2.5-fold enhancement in $\mathrm{C}_{\max }, \mathrm{AUC}_{0-\infty}, \mathrm{T}_{1 / 2}$, and MRT, respectively, than free curcumin. Noteworthy, CUNC showed 3-, 2.3-, 1.4-, and 1.6-fold enhancement in $\mathrm{C}_{\max }, \mathrm{AUC}_{0-\infty}, \mathrm{T}_{1 / 2}$, and MRT, respectively, compared to 
Table 7. Estimated pharmacokinetic parameters of curcumin, CU-NL, and CU-NC after oral administration in plasma samples of Wistar albino rats

\begin{tabular}{cccc}
\hline Parameters & Curcumin & CU-NL & CU-NC \\
\hline Dose $(\mathrm{mg} / \mathrm{kg})$ & 50 & 50 & 50 \\
$\mathrm{C}_{\max }(\mu \mathrm{g} / \mathrm{mL})$ & $6.92 \pm 2.15$ & $32.57 \pm 8.97$ & $97.69 \pm 10.84$ \\
$\mathrm{~T}_{\max }(\mathrm{h})$ & 3 & 6 & 6 \\
$\mathrm{AUC}_{(0-\mathrm{t})}[(\mu \mathrm{g} / \mathrm{mL}) \cdot \mathrm{h}]$ & $56.49 \pm 3.57$ & $499.43 \pm 8.98$ & $996.41 \pm 10.38$ \\
$\mathrm{AUC}_{(0-\infty)}[(\mu \mathrm{g} / \mathrm{mL}) \cdot \mathrm{h}]$ & $63.33 \pm 5.38$ & $598.17 \pm 5.61$ & $1402.77 \pm 9.67$ \\
$\mathrm{AUMC}_{(0-\mathrm{t})}\left[(\mu \mathrm{g} / \mathrm{mL}) \cdot \mathrm{h}^{2}\right]$ & $378.06 \pm 5.37$ & $4673.76 \pm 6.37$ & $12032.50 \pm 12.87$ \\
$\mathrm{AUMC}_{(0-\infty)}\left[(\mu \mathrm{g} / \mathrm{mL}) \cdot \mathrm{h}^{2}\right]$ & $612.42 \pm 4.68$ & $9121.91 \pm 12.38$ & $35140.16 \pm 14.67$ \\
$\mathrm{t}_{1 / 2}(\mathrm{~h})$ & $7.11 \pm 0.81$ & $14.59 \pm 0.67$ & $20.72 \pm 0.97$ \\
$\mathrm{~K}_{\mathrm{e}}(\mathrm{h}-1)$ & $0.10 \pm 0.005$ & $0.05 \pm 0.002$ & $0.03 \pm 0.008$ \\
$\mathrm{MRT}(\mathrm{h})$ & $9.67 \pm 1.24$ & $15.25 \pm 2.37$ & $25.05 \pm 2.19$ \\
$\mathrm{CL}(\mathrm{L} / \mathrm{h} \cdot \mathrm{kg})$ & $0.79 \pm 0.08$ & $0.08 \pm 0.015$ & $0.04 \pm 0.012$ \\
$\mathrm{~V}_{\mathrm{D}}(\mathrm{L} / \mathrm{kg})$ & $8.07 \pm 1.30$ & $1.76 \pm 0.27$ & $1.17 \pm 0.24$ \\
$\mathrm{~F}_{\text {rel }}(\%)$ & - & 944.53 & 2215.02 \\
\hline
\end{tabular}

CU-NL. A significant difference was also observed in the $\mathrm{T}_{\max }$ of CU-NC and free curcumin administered rats.

Conclusively, CU-NC exhibited the 22- and 2.3-fold improvements in oral bioavailability of curcumin compared to curcumin dispersion and CU-NL. This improvement is attributed to the improved absorption, improved MRT, enhanced contact time with wall of intestine, reduced metabolism, lesser macrophage uptake, and prolonged release of curcumin from intact and stable structure of nanocochleates.

\section{6. 2. Biodistribution Study}

Compared to free curcumin, CU-NC showed 2.9-, $1.5-, 3.1-$, and 1.35-fold reduced distribution to spleen, heart, liver, and kidney, whereas 1.9- and 3.4-fold higher distribution was observed to brain and lungs, respectively. Compared to CU-NL, CU-NC showed 1.3-, 1.2-, 1.9-, and 1.2-fold reduction in distribution to spleen, heart, liver, and kidney, respectively. This may be attributed to a lower volume of distribution of CU-NC, as revealed in bioavailability study. Lower distribution of curcumin from $\mathrm{CU}-\mathrm{NC}$ to spleen and liver suggests that the CU-NC diminishes the elimination of curcumin through reticuloendothelial system (RES). Compared to CU-NL, CU-NC showed 1.4- and 2.0-fold higher distribution to brain and lungs, respectively (Fig. 7B). These results confirm the potential of CU-NC to preferentially target the curcumin to brain and lungs. Hence, the obtained results undoubtedly corroborate the efficacy of the developed method with the purpose of implementation to the therapeutic drug monitoring and pharmacokinetic analysis.

\section{Conclusion}

An accurate, simple, rapid, robust, and reliable HPLC method was developed and optimized for the quan- titative determination of curcumin in rat plasma. Different pharmacokinetic parameters were also estimated after the oral administration of CU-NC and CU-NL. A developed method precisely determined the minute quantity of curcumin. Hence, the method can be used routinely to analyze the curcumin from the different pharmaceutical formulations and can be explored for clinical applications and further studies.

\section{Acknowledgments and Funding}

This research received no specific grant from any funding agency in the public, commercial, or not-for-profit sectors.

\section{Disclosure statement}

Authors have no conflicts of interest to disclose.

\section{References}

1. B. Fonseca-Santos, M. P. D. Gremiao, M. Chorilli, Arabian J. Chem. 2017, 10, 1029-1037.

DOI:10.1016/j.arabjc.2016.01.014

2. L. Hui-Tien, H. Yuan-Soon, Food Sci. Human Wellness 2018, 7, 134-137. DOI:10.1016/j.fshw.2018.06.001

3. B. C. Jordan, C. D. Mock, R. Thilagavathi, C. Selvam, Life sci. 2016, 152, 135-144. DOI:10.1016/j.lfs.2016.03.036

4. Z. C. Gersey, G. A. Rodriguez, E. Barbarite, A. Sanchez, W. M. Walters, K. C. Ohaeto, R. M. Graham, BMC Cancer 2017, 17, 99. DOI:10.1186/s12885-017-3058-2

5. T. Zhang, Y. Chen, Y. Ge, Y. Hu, M. Li, Y. Jin, Acta Pharmaceutica Sinica B. 2018, 8, 440-448.

DOI:10.1016/j.apsb.2018.03.004

6. C. Moorthi, C. S. Kumar, S. Mohan, K. Krishnan, K. Kathiresan, J. pharm. res. 2013, 7, 224-229.

DOI:10.1016/j.jopr.2013.03.006 
7. S. J. Nadaf, S. G. Killedar, J. Drug Del. Sci. Techn. 2018, 47, 337-350. DOI:10.1016/j.jddst.2018.06.026

8. M. R. Peram, S. S. Jalalpure, S. A. Joshi, M. B. Palkar, P. V. Diwan, J. Liq. Chromatogr. R. T. 2017, 40, 487-498.

DOI:10.1080/10826076.2017.1329742

9. C. Mohanty, M. Das, S. K. Sahoo, Expert Opin. Drug Deliv. 2012, 9, 1347-1364. DOI:10.1517/17425247.2012.724676

10. R. A. Silva-Buzanello, A. C. Ferro, E. Bona, L. Cardozo-Filho, P. H. Araujo, F. V. Leimann, O. H. Gonçalves, Food Chem. 2015, 172, 99-104. DOI:10.1016/j.foodchem.2014.09.016

11. M.vA. Korany, R. S. Haggag, M. A. A. Ragab, O. A. Elmallah, Arabian J. Chem. 2017, 10, S1711-S1725.

DOI:10.1016/j.arabjc.2013.06.021

12. V. P. Shah, K. K. Midha, S. Dighe, I. J. McGilveray, J. P. Skelly, A. Yacobi, et al.,. Eur. J. Drug Metab. Pharmacokinet. 1992, 16(4), 249-255.

13. P. V. Kadam, C. L. Bhingare, R. Y. Nikam, S. A. Pawar, Pharm. Methods 2013, 4, 43-45. DOI:10.1016/j.phme.2013.08.002

14. K. Ahmed, Y. Li, D. J. McClements, H. Xiao, Food Chem. 2012, 132, 799-807. DOI:10.1016/j.foodchem.2011.11.039

15. S. J. Nadaf S. G. Killedar, Pharm. Methods 2018, 9, 56-63. DOI:10.5530/phm.2018.2.11

16. H. K. Syed, K. B. Liew, G. O. Loh, K. K. Peh, Food Chem. 2015 , 170, 321-326. DOI:10.1016/j.foodchem.2014.08.066

17. J. Mahale, L. M. Howells, R. Singh, R. G. Britton, H. Cai, K. Brown, Biomed. Chromat. 2018, e4280. DOI: $10.1002 / \mathrm{bmc} .4280$

18. Y. Long, W. Zhang, F. Wang, Z. Chen, J. Pharma. Anal. 2014, 4, 325-330. DOI:10.1016/j.jpha.2013.10.002

19. H. S. Koop, R. A. de Freitas, L. M. de Souza, G. R. Martinez, J. L. M. Silveira, Chromatogr. 2013, 76, 1041-1048.

DOI:10.1007/s10337-013-2402-1

20. Guidance for Industry, Bioanalytical Method Validation, U.S. Department of Health and Human Services, Food and Drug Administration Centre for Drug Evaluation and Research
(CDER), Centre for Veterinary Medicine (CVM), May, 2001. 21. S. Kharat, A. Namdeo, P. Mehta, J. Taibah Univ Sci. 2017, 11, 775-781. DOI:10.1016/j.jtusci.2016.10.004

22. V. A. Pkekre, S. G. Walode, Int. J. Pharm. Sci. Res. 2012, 3, 3796-3800.

23. S. R. Kunati, S. Yang, B. M. William, Y. Xu, J. Pharm. Biomed. Anal. 2018, 156, 189-198. DOI:10.1016/j.jpba.2018.04.034

24. Y. Cao, R. X. Xu, Z. Liu, J. Chromatogr. B Analyt. Technol. Biomed. Life Sci. 2014, 949-950, 70-78.

DOI:10.1016/j.jchromb.2013.12.039

25. T. C. F. do Nascimento, D. M. Casa, L. F. Dalmolin, A. C. de Mattos, N. M. Khalil, R. M. Mainardes, Curr. Pharm. Anal. 2012, 8, 324. DOI:10.2174/157341212803341654

26. B. Kurangi, S. Jalalpure, S. Jagwani, J. Chromatogr. B. 2019, 1122-1123, 39-48. DOI:10.1016/j.jchromb.2019.05.017

27. S. Kongkiatpaiboon, N. Duangdee, S. Chewchinda, O. Poachanukoon, K. Amnuaypattanapon, J. King Saud Univ. Sci. 2019, 31, 48-51. DOI:10.1016/j.jksus.2017.05.016

28. S. S. Perumal, S. P. Ekambaram, S. Raja, J. food drug anal. 2014, 22, 520-526. DOI:10.1016/j.jfda.2014.05.003

29. S. Deya, S. S. Patro, N. S. Babu, P. N. Murthy, S. K. Panda, J. Pharm. Anal. 2017, 7, 134-140.

DOI:10.1016/j.jpha.2013.12.002

30. L. Xie, X. N. Li, D. X. Jiang, D. Zhang, J. Pharm. Anal. 2011, 1, 297-301. DOI:10.1016/j.jpha.2011.09.004

31. J. Bland, D. Altman, The Lancet. 1986, 327, 307-310. DOI:10.1016/S0140-6736(86)90837-8

32. J. Bland, D. Altman, Stat. Methods in Medical Res. 1999, 8, 135-160. DOI:10.1191/096228099673819272

33. S. Koppel, S. Chang, Procedia Manufacturing. 2016, 5, 122131. DOI:10.1016/j.promfg.2016.08.012

34. F. S. Bandarkar, P. R. Vavia, Trop. J. Pharm. Res. 2009, 8, 257264. DOI:10.4314/tjpr.v8i3.44543

35. P. Masson, J. Chromatogr. A. 2007, 1158, 168-173. DOI:10.1016/j.chroma.2007.03.003

\section{Povzetek}

Razvili in validirali smo zanesljivo RP-HPLC analizno metodo z UV detekcijo pri $421 \mathrm{~nm}$ za kvantitativno določanje kurkumina v podganji plazmi po oralni administraciji s kurkuminom napolnjenih nanoškoljkic (nanokohleati, CU-NC) podganam. Kromatografska ločba je potekala na koloni HIQ SIL, C18 (250 mm × 4,6 mm) z metanolom in vodo (80:20 $v / v)$ kot mobilno fazo pri pretoku $1,0 \mathrm{~mL} / \mathrm{min}$. Preverjali smo naslednje validacijske parametre: linearnost, točnost, natančnost, mejo določanja in mejo zaznave. Linearnost je bila potrjena $\mathrm{v}$ območju $2,5-100 \mu \mathrm{g} / \mathrm{mL}$ kurkumina $\left(\mathrm{R}^{2}=\right.$ 0,9979). Razvita HPLC metoda je bila natančna $\mathrm{z}<2 \%$ relativnega standardnega odmika. Tudi parametri točnosti, stabilnosti in robustnosti so bili sprejemljivi. Bland-Altman graf je pokazal sprejemljiv koeficient ponovljivosti. Metoda je bila statistično kontrolirana, kar je bilo razvidno iz kontrolne karte. Po administraciji CU-NC podganam smo določili naslednje farmakokinetične parametre: $\mathrm{C}_{\max } 97,69 \pm 10,84 \mu \mathrm{g} / \mathrm{mL}, \mathrm{AUC}_{0-\infty} 1402,77 \pm 9,67(\mu \mathrm{g} / \mathrm{mL}) \cdot \mathrm{h}$ in $\mathrm{AUMC}_{0-\infty}$ $35140,16 \pm 14,67(\mu \mathrm{g} / \mathrm{mL}) \cdot \mathrm{h}^{2}$. To preprosto in natančno metodo lahko učinkovito uporabimo za rutinske analize.

Except when otherwise noted, articles in this journal are published under the terms and conditions of the Creative Commons Attribution 4.0 International License 